\title{
PEMANFAATAN BUKU TEKS MEMBUATKU SEMAKIN BERKARAKTER SEBAGAI SUMBER DALAM PEMBELAJARAN PENULISAN TEKS PERCAKAPAN DI KELAS VI SDN PATEBON
}

\author{
Nur Aini Saura Putri ${ }^{1}$, Rizka Nur Oktaviani ${ }^{2}$, Endah Wening Subekti ${ }^{3}$ \\ STKIP Bina Insan Mandiri ${ }^{1}$, STKIP Bina Insan Mandiri ${ }^{2}$, STKIP Bina Insan Mandiri ${ }^{3}$ \\ Pos-el: nurainisaura@stkipbim.ac.id ${ }^{1}$, rizkanuroktaviani@stkipbim.ac.id ${ }^{2}$, \\ endahwening@stkipbim.ac.id ${ }^{3}$
}

\begin{abstract}
ABSTRAK
Buku teks merupakan salah satu panduan bagi siswa dalam mengikuti proses belajar mengajar. Pembelajaran bahasa Indonesia di tingkat sekolah dasar mencangkup semua aspek keterampilan bahasa, salah satunya keterampilan menulis. Ketrampilan menulis merupakan aspek penting dalam pembelajaran bahasa Indonesia. melalui kegiatan menulis teks percakapan ini siswa mampu menuangkan ide-ide dan majinasi melalui bahasa tulis. Berdasarkan hasil observasi menunjukkan bahwa keterampilan menulis siswa SDN Patebon sudah cukup baik. Tujuan penelitian ini untuk mendeskripsikan pemanfaatan buku teks Membuatku Semakin Berkarakter sebagai sumber belajar dalam pembelajaran penulisan teks percakapan di kelas VI. Rancangan penelitian ini menggunakan metode deskriptif, penelitian kulitatif. Teknik dalam penelitian ini menggunakan teknik observasi dan wawancara. Hasil penelitian menunjukkan bahwa guru sangat terbantu dengan adanya buku teks Membuatku Semakin Berkarakter. Dikarenakan di dalam buku ini sudah ada contoh-contoh teks percakapan yang sangat membantu untuk memberikan pemahaman terhadap siswa. Buku teks Membuatku Semakin Berkarakter juga sangat membantu bagi siswa untuk memahami bentuk teks percakapan, karena ada beberapa bentuk contoh yang dapat memberikan mereka pemahaman secara jelas. Jadi dapat disimpulkan bahwa dalam pembelajaran penulisan teks percakapan di SDN Patebon dengan menggunakan buku teks Membuatku Semakin Berkarekter sangat membantu berjalannya proses belajar mengajar.
\end{abstract}

Kata Kunci: Pemanfaatan Buku Teks, Sumber Belajar, Keterampilan Menulis.

\begin{abstract}
Textbooks are a guide for students to follow the teaching and learning process. Indonesian language learning at the elementary school level covers all aspects of language skills, one of which is writing skills. Writing skills are an important aspect in learning Indonesian. through this conversation text writing activity students are able to express ideas and gradations through written language. Based on observations, it shows that the writing skills of Patebon Elementary School students are good enough. The purpose of this study is to describe the use of textbooks to Make Me More Character as a source of learning in learning to write conversational text in class VI. This research design uses descriptive method, skin research. The technique in this study uses observation and interview techniques. The results showed that the teacher was greatly helped by the existence of textbooks Making Me More Character. Because in this book there are examples of conversational texts that are very helpful to give understanding to students. Textbooks Make Me More Characteristic is also very helpful for students to understand the form of conversational texts, because there are several forms of examples that can give them a clear understanding. So it can be concluded that in learning the conversation text writing in Patebon Elementary School by using textbooks Making Me More Interdependent greatly helped the process of teaching and learning.
\end{abstract}




\section{Keywords: Utilization Textbooks, Learning Resources, Writing Skill}

\section{PENDAHULUAN}

Bahasa Indonesia merupakan salah satu mata pelajaran yang diutamakan. Pembelajaran bahasa Indonesia mencangkup semua aspek keterampilan dalam berbahasa, diantaranya keterampilan menyimak, keterampilan berbicara, keterampilan membaca, dan keterampilan menulis. Tarigan (2008:1) menyatakan bahwa setiap keterampilan tersebut erat sekali berhubungan dengan tiga keterampilan lainnya dengan cara beranekaragam. Keempat keterampilan tersebut saling berkaitan dan dapat dijadikan sebagai bekal siswa dalam proses belajar di sekolah. Siswa pada tahapan sekolah dasar sudah melalui keempat ketrampilan tersebut. Di sekolah dasar terdapat pembelajaran menulis teks dialog atau teks percakapan yang masuk kedalam lingkup keterampilan menulis, meskipun pada dasarnya telah juga melalui ketrampilan menyimak dan membaca. Sebelum melakukan kegiatan pembelajaran menulis siswa juga telah membaca materi di dalam buku teks yang bertujuan untuk memberikan wawasan dan pengetahuan terhadap materi keterampilan menulis percakapan.

Proses pembelajaran menulis, kualitas buku teks menjadi hal penting dalam meningkatkan kualitas serta minat siswa dalam menulis. Buku teks merupakan panduan bagi siswa dalam mengikuti pembelajaran. Dengan adanya buku teks yang baik diharapkan siswa dapat menggunakannya sebagai sumber gagasan dan panduan dalam melaksanakan kegiatan pembelajaran. Buku teks berisikan berbagai informasi tentang ilmu pengetahuan tertentu sesuai dengan mata pelajaran dan jenjang. Buku teks sebagai buku pendamping mulai dari sekolah dasar (SD) sampai perguruan tinggi (PT). Buku teks biasa digunakan oleh para penulisnya untuk menyampaikan ilmu pengetahuan sesuai dengan perkembangan ilmu tersebut. Buku teks sebagai sumber utama bagi siswa yang mengandung banyak mengandung ilmu pengetahuan yang disusun menurut logika, disajikan secara runtut dan sedapat mungkin memenuhi tuntutan kurikulum. Lebih jelas lagi mengenai buku teks juga dijelaskan oleh Pemerintah melalui Peraturan Menteri Pendidikan Nasional Nomor 2 tahun 2008. Buku teks adalah buku acuan wajib untuk digunakan disatuan pendidikan dasar dan menengah atau perguruan tinggi yang memuat materi pembelajaran dalam rangka peningkatan keimanan, ketakwaan, akhlak mulia, dan kepribadian, penguasaan ilmu pengetahuan dan teknologi, peningkatan kepekaan dan kemampuan estetis, penimgkatan kemampuan kinestetis dan kesehatan yang disusun berdasarkan standr nasional pendidikan (Permendiknas No 2 Tahun 2008). Buku teks memberikan pengaruh yang cukup penting dalam proses belajar megajar. Karena di dalam buku teks berisi materimateri pembelajaran dan juga contohcontoh sebagai bahan ajar.

Buku teks memberikan pengaruh yang cukup signifikan dalam proses belaar mengajar. Cunningsworth (Sumardi, 2000:1) tidak ada sesuatu yang pengaruhnya lebih besar terhadap isi dan pelaksanaan kegiatan belajar mengajar selain buku pelajaran dan bahan ajar lainnya. Sesuai dengan pendapat di atas bahwa buku teks atau buku ajar merupakan alat ajar yang mampu memberikan pengaruh cukup besar. Buku teks juga dapat digunakan sebagai media pembelajaran. Secara teknis terdapat beberapa syarat buku teks dikatakan berkualitas. Menurut Geene dan Pety yang dikutip Tarigan (2009: 21) menyodorkan sepuluh kategori yang harus dipenuhi buku teksa yang 
berkualitas, yaitu (1) menarik minat siswa yang mempergunakannya, (2) mampu memberikan motivasi kepada para siswa yang memakainya, (3) memuat ilustrasi yang menarik siswa yang memnafaatkannya, mempertimbangkan aspek-aspek linguistik sehingga sesuai dengan kemampuan para siswa yang memakainya, (5) berhubungan erat dengan pelajaran-pelajaran lainnya, lebih baik lagi kalua dapat menunjangnya dengan terencana sehingga semuanya merupakan suatu kebulatan yang utuh dan terpadu, (6) dapat menstimuli, merangsang aktivitas-aktivitas pribadi para siswa yang mempergunakannya, (7) dengan sadar dan tegas menghinda dari konsep-konsep yang samar-saar dan tidak biasa, agar tidak membuat ingung siswa yang memakainya, (8) memounyai sudut pandang atau "point of view" yang jelas dan tegas sehingga pada akhirnya juga menjadi sudut pandang para pemakainya yang setia, (9) mampu memberikan pemantapan, penekanan pada nilai-nilai anak dan orang dewasa, (10) dapat menghargai perbedaanperbedaan pribadi para pemakainya. Kesepuluh ciri buku teks yang berkualitas ini dapt dijadikan pedoman untuk mengetahui buku teks yang baik digunakan.

Dalam memperbaiki kualitas siswa tidak hanya dapat mengandalkan media ajar, namun juga dari semangat siswa dalam belajar. Walker (Riyanto, 2002:5) belajar adalah sesuatu perubahan dalam pelaksanaan tugas yang terjadi sebagai hasil dari pengalaman dan tidak ada sangkut pautnya dengan kematangan rohaniah, kelelahan, motivasi, perubahan dalam situasi stimulus atau faktor-faktors amarsamar lainnya. Oleh karena itu belajar juga menjadi faktor utama dalam berhasilnya proses belajar mengajar.

Dalam pembelajaran menulis percakapan siswa difokuskan pada keterampilan menulis yaitu melalui tugas menulis sebuah teks percakapan. Ketrampilan menulis merupakan aspek penting dalam pembelajaran bahasa Indonesia, karena melalui keterampilan bahasa ini guru dapat mengetahui seberapa faham siswa terhadap materi yang telah diajarkan. Karena melalui kegiatan menulis teks percakapan ini siswa mampu menuangkan ide-ide dan majinasi melalui bahasa tulis. menulis adalah keterampilan berbahasa yang paling sulit dikuasai, karena menulis bukan hanya sekedar menyalin atau menuangkan bahasa lisan ke dalam sebuah tulisan, Tetapi menulis juga harus bisa mengembangkan suatu gagasan kedalam suatu strukturt ulisan yang teratur. Sementara itu, menurut Tarigan (2008:3), menulis merupakan kegiatan produktif dan ekspresif yang diinginkan untuk berekspresi yang di inginkan untuk berkomunikasi secara tidak langsung, tidak secara tatap muka dengan orang lain dan juga dapat digunakan sebagai laporan.

Oleh karena itu dengan adanya kegiatan menulis siswa mampu mengekspresikan ide dan imajinasinya kedalam bahasa tulis melalui belajar membuat teks percakapan. Menurut Irene (dalam Afiatin, Nurdin dan Seni, 2015:56), percakapan atau dialog merupakan suatu pembicaraan dari percakapan atau dialog dengan orang lain. Sementara itu Rusyani (dalam Cahyani, 2006:100), menjelakan bahwa tulisan dialog adalah terdiri dari kalimatkalimat langsung antara pembicara dengan orang lain yang berperan sebagai pendengar secara bergantian. Kegiatan siswa dalam ketrampilan menulis memerlukan kemampuan mengusai ejaan, tanda baca, penggunaan huruf capital dan penulisan kata. Oleh karena itu, guru sebaiknya bertugas sebagai sumber informasi dan fasilitator bagi siswa untuk mengembangkan potensi yang dimiliki.

Berdasarkan hasil observasi di SDN Patebon, Pasuruan menunjukkan 
bahwa siswa mampu membuat karya tulis. Saat diberi tugas oleh guru untuk membuat teks percakapan mereka dapat membuatnya. Namun beberapa siswa masih kesulitan, hal ini dikarenakan tidak ada contoh teks percakapan yang diberikan oleh guru. Sehingga beberapa siswa merasa kesulitan dalam membuat teks percakapan. Saat memberikan tugas guru juga tidak memberikan tema mengenai teks percakapan yang harus mereka buat. Sehingga beberapa siswa merasa kesulitan dalam menentukan topik atau ide dalam tulisannya. Dengan adanya buku teks Membuatku Semakin Berkarekter dapat mempermudah siswa kelas VI SDN Patebon dalam memahami materi keterampilan menulis teks percakapan.

Berdasarkan latar belakang di atas, maka dilakukan penelitian sebagai upaya untuk mendeskripsikan pemanfaatan buku teks Membuatku Semakin Berkarakter sebagai bahan ajar. Maka judul penelitian ini adalah "Pemanfaatan Buku Teks Membuatku Semakin Berkarakter sebagai Sumber Belajar dalam Pembelajaran Penulisan Teks Percakapan di Kelas VI". Adapun tujuan penelitian ini untuk mendeskripsiskan pemanfaatan buku teks dalam pembelajaran menulis teks percakapan di kelas VI Sekolah Dasar.

\section{METODE PENELITIAN}

Penelitian ini dilakukan di SDN Patebon pada kelas VI. Penelitian ini merupakan penelitian kualitatif. Disebut sebagai penelitian kualitatif karena datanya bukan merupakan angka-angka, melainkan kata-kata yang menggambarkan sebauh deskripsi sesuatu hal. Sesuai dengan pendapat Moleong (2012:49) mengemukakan bahwa dalam penelitian kualitatif data yang dikumpulkan adalah berupa katakata, gambar, bukan angka-angka. Dapat disimpulkan bahwa penelitian yang berisi kata-kata berupa deskripsi merupakan penelitian kualitatif.
Penelitian ini menggunakan metode deskriptif. Penggunaan metode deskriptif pada penelitian ini berdasarkan penelitian yang bertujuan untuk menggambarkan objek penelitain berdasarkan fakta-fakta sebagaimana adanya. Hal ini sejalan dengan pendapat Nawawi (2005:83) bahwa metode deskriptif dapat diartikan sebagai prosedur pemecahan masalah yang diselidiki dengan menggambarkan atau melukiskan keadaan subjek atau objek penelitian (seseorang, lembaga, masyarakat, dll) pada saat sekarang berdasarkan pada fakta-fakta yang tampak atau sebagaimana adanya. Sejalan dengan hal tersebut Sutopo (2006:136) penelitian kualitatif akan mampu menangkap berbagai informasi kualitatif dengan deskripsi teliti dan penuh nuansa yang lebih berharga daripada sekedar pernyataan jumpah ataupun frekuensi dalam bentuk angka. Lebih lanjut Sutopo (2006: 155) menjelaskan bahwa penelitian salah satu kkarakteristik pokoknya insrumen penelitian utama adalah penelitinya, hal ini sering disebut "human isntrument". Dimana adalam penelitian ini peneliti lah yang lebih tau bagaimana pemanfaatn buku teks dalam prosess pembelajara, selain melakukan studi kasus di dalam kelas peneliti juga melakukan wawancara terhadap guru dan siswa.

Teknik pengumpulan data pada penelitian ini berupa penelitian secara langsung, dengan melakukan observasi kelas dan wawancara terstruktur. Observasi kelas dilakukan untuk mengetahui bagaimana guru dan siswa dalam proses belajar di kelas. Observasi dan pengamatan ini dilakukan saat proses pembelajaran menulis teks percakapan dengan menggunakan buku teks Membuatku Semakin Berkarakter. Data observasi berupa deskripsi yang faktual, cermat, serta konteks di mana kegiatan terjadi.

Wawancara dilakukan untuk menyajikan konstruksi saat sekarang 
dalam suatu konteks mengenai pribadi, peristiwa, aktivitas, organisasi, perasaan, motivasi, tanggapan, atau persepsi, tingkat atau bentuk leterlibatan. Ada empat variabel yang sangat penting dalam menentukan keberhasilan wawancara, yaitu pewawancara (interviewer), responden (interviewee), daftar pertanyaan atau pedoman pertanyaan (interview guide) yang dipakai, dan repport antara pewawancara dengan responden (Vredenbregt, 1978:84). Adanya persiapan yang matang dalam menyusun pertanyaan menjadi dasar lancarnya proses wawancara.

Pengumpulan data dilakukan dengan (a) melakukan pengamatan kelas (b) mempersiapkan pertanyaan sebagai alat melaksanakan wawancara berdasarkan rumusan masalah, (c) melaksanakan wawancara terhadap guru dan siswa kelas VI SDN Patebon dengan bantuan alat rekan Handphone, (d) mentranskrip hasil wawancara, (e) mengklasifikasikan hasil wawancara sesuai dengan rumusan masalah penelitian.

\section{HASIL DAN PEMBAHASAN Hasil Penelitian}

Gambaran umum buku teks Membuatku Semakin Berkarakter pada tema 2 Persatuan dalam Perbedaan menjelaskan mengenai bagaimana bentuk teks percakapan dalam bentuk komik singkat. Dengan gambar percakapan seorang ibu guru dan dua murid. Menceritakan tentang dua siswa baru baru yang sedang memperkenalkan diri, satu siswa memperkenalkan diri dengan bahasa Surabaya dan satu siswa lagi dari Ambon. Kemudian ada siswa yang menertawakan dua temannya yang menggunakan bahasa daerah. Ibu guru mencoba menjelaskan bahwa itu merupakan bahasa daerah, dan memberikan penjelasan kepada dua siswa baru tersebut agar menggunakan bahasa Indonesia yang benar.
Percakapan ini menggambarkan mengenai perbedaan dalam berbahasa daerah, namun dapat disatukan dengan bahasa persatuan yaitu bahasa Indonesia. Guru menugaskan siswa untuk membaca teks percakapan berbentuk komik tersebut. Kemudian siswa ditugaskan untuk menuliskan informasi yang didapat dari percakapan tersebut. bentuk komik seperti ini mempermudah siswa untuk memahami isi teks percakapan tersebut.

\section{Pembahasan}

Berdasarkan hasil wawancara pada teks percakapan berbentuk komik ini membuat siswa lebih mudah memahami isinya. Seperti pada potongan hasil wawancara saya pada salah satu siswa kelas VI SDN Patebon saat saya menanyakan apakah dia dapat menjelaskan tentang isi dari percakapan tersebut.

"ceritanya ada anak baru pakai bahasa jawa bu, lalu bu guru memperingatkan agar mereka menggunakan bahasa Indonesia yang baik dan benar" (Rian)

Dari jawaban tersebut terlihat bahwa siswa sudah lebih mudah memahami teks percakapan ketika dalam bentuk komik (bergambar).

Selain siswa, guru juga dimudahkan dengan menggunakan buku teks Membuatku Semakin Berkarakter. Dengan adannya contoh teks percakapan yang berbentuk komik di dalam bukuteks tersebut guru tidak perlu kesulitan mencari contoh melalui internet. Dikarenakan guru kurang mampu dalam mengoperasikan internet, sehingga media buku yang berisi contohcontoh yang menarik mempermudah guru dalam melaksanakan proses belajar mengajar.

Dari sini dapat dilihat bahwa buku Teks Bahasa Indonesia Membuatku Semakin Berkarakter termasuk buku yang berkualitas terdapat pada poin 3 terdapat ilustrasi yang 
mempermudah penggunanya. Seperti yang telah diungkapkan Tarigan (2009: 21) pada poin 3 tentang buku teks yang berkualitas yang memuat ilustrasi yang menarik siswa yang memnafaatkannya.

Disubab selanjutnya terdapat contoh mengenai teks percakapan dengan bentuk wawancara antara seorang siswa dengan Pak RT. Isi percakapan tersebut mengenai wawancara tentang lingkungan sekitar yang mulai terkena wabah demam berdarah. Pada subab ini siswa ditugaskan untuk memperagakan teks percakapan di depan kelas. Pada hasil observasi yang dilakukan banyak siswa yang antusias untuk maju ke depan dengan pasangan membacakan teks percakapan tersebut. yang satu berperan sebagai siswa yang lainnya berperan sebagai Pak RT. Dengan adanya contoh teks percakapan berisi wawancara seperti ini mempermudah guru untuk menjelaskan bentuk teks percakapan wawancara. Hal ini juga mempermudah siswa untuk mengetahui bentuk langsung teks wawancara. Sehingga ketika siswa ditugaskan untuk membuat teks percakapan wawancara akan lebih mudah. Setelah dibacakapan teks tersebut terdapat beberapa pertanyaan sebagai latihan individu. Tes ini sebagai salah satu cara agar siswa memperhatikan teman-teman yang sedang membaca teks percakapan di depan kelas.

Subab selanjutnya yang menjadi fokus utama penelitian ini, yaitu mengenai menulis teks percakapan. Terdapat sedikit pengertian dan contoh mengenai cara membuat pertanyaan, membuat kalimat anjuran, dan membuat kalimat permintaan. Disubab-subab sebelumnya sudah ada cotoh mengenai teks percakapan. Baik berbentuk komik maupun berbentuk teks percakapan drama yang berisi tentang wawancara. Untuk mempermudah siswa membuat teks percakapan, di dalam buku teks Membuatku Semakin Berkarakter disediakan sebuah cerpen untuk dibaca siswa. Selanjutnya siswa ditugaskan untuk membuat teks percakapn dalam bentuk teksa drama. Berdasarkan hasil teks wawancara terhadap beberapa siswa, mereka mengaku sangat terbantu dengan adanya buku teks ini. Terutama dalam membuat teks percakapan, karena suadah ada cerpen sebagai bahan untuk diubah ke teks percakapan. Selain itu contoh-contoh yang membuat mereka lebih mudah memahami bentuk teks percakapan.

"sudah ada contohnya, jadi gampang bu buat teks percakapannya" (Muhammad)

"cerpennya ini yang bikin mudah bu, soalnya tidak perlu cari tema lagi" (Dika)

"ada cerpen ini, jadi mudah, gak perlu mikir kalimatnya" (Risa)

Dari beberapa pemaparan di atas terlihat bahwa siswa mudah memahami mengenai teks percakapan. Dengan adanya beberapa contoh dan cerpen sebagai bahan membuat teks percakapan, mempermudah siswa untuk membuat teks percakapan. Guru sangat terbantu dengan cerpen yang ada dalam buku teks Membuatku Semakin Berkarakter, sehingga guru tidak perlu mencari lagi cerpen sebagai bahan latihan untuk mahasiswa membuat teks percakapan.

Berdasarkan pemaparan di atas dapat disimpulkan bahawa buku teks Bahasa Indonesia membuatku semakin berkarakter termasuk dalam buku berkualitas, yang mampu memotivasi siswa dalam membuat teks percakapan. Hal ini sejalan dengan Geene dan Pety yang dikutip Tarigan (2009: 21) pada poin 2 yaitu mampu memberikan motivasi kepada para siswa yang memakainya dan poin 6 yaitu dapat menstimuli, merangsang aktivitasaktivitas pribadi para siswa yang mempergunakannya. Cerpen yang ada pada buku Teks Membuatku Semakin Berkarakter dapat memotovasi dan 
menstimuli siswa dalam membuat teks percakapan.

Pemanfaatan buku teks bahasa Indonesia Membuatku Semakin Berkarakter dalam proses pembelajaran di kelas VI SDN Patebon di rasa cukup membantu. Panduan dan penjelasan materi yang ada di dalam buku tersebut dapat membantu siswa untuk lebih mudah memahami materi, khususnya dalam materi menulis teks percakapan.

Penelitian yang dilakukan di SDN Patebon terhadap makna buku teks Membuatku Semakin Berkarakter memberikan kesan baik. Meskipun saat ini banyak berkembang berbagai jenis media yang bisa dimanfaatkna dalam pembelajaran, namun buku teks masih dianggap penting. Hal ini dikarenakan di dalam buku teks terdapat bacaan tentang materi sekaligus panduan pemeblajaran dan soal-soal latihan yang dapat digunakan oleh guru. Demikian juga untuk buku teks Membuatku Semakin Berkarakter memberikan kemudahan untuk guru maupun siswa dalam memahami materi. Buku teks ini juga bersifat praktis dan dapat dimanfaatkan sebagai sumber maupun media pembelajaran.

Berdasarkan pengamatan di dalam kelas VI SDN Patebon serta hasil wawancara dari beberapa siswa yang dilakukan setelah proses belajar mengajar di kelas selesai. Wawancara dilakukan pada beberapa siswa dengan dipilih secara acak. Siswa memberikan keterangan bahwa proses belajar mengajar yang diberikan oleh guru dengan menggunakan buku teks Membuatku Semakin Barkarakter membuat mereka lebih mudah dalam memahami materi mengenai menulis teks percakapan, adanya contoh dalam buku teks juga mempermudah mereka memahami materi

\section{SIMPULAN}

Berdasarkan dari pembahasan di atas dapat disimpulkan bahwa guru dan siswa SDN Patebon telah dapat memanfaatkan buku teks Membuatku Semakin Berkarakter secara optimal. Dalam pembelajaran menulis teks percakapan guru dipermudah dengan adanya contoh teks percakapan. Selain itu terdapat cerpen yang mempermudah guru untuk dijadikan bahan dalam memberikan tugas teks percakapan pada siswa. Buku teks ini juga memberikan kemudahan bagi siswa untuk memahami teks percakapan secara konkrit, mulai teks percakapan berbentuk komik maupun dalam bentuk teks drama. Adanya cerpen yang digunakan untuk latihan siswa membuat teks percakapan juga mempermudah siswa. Hal ini dikarenakan siswa hanya cukup mengubah cerpen ke dalam teks percakapan, tanpa perlu memikirkan tema maupun kalimat dalam teks percakapan. Hanya perlu sedikit improvisasi untuk memperindah teks percakapan yang mereka buat.

Adapun saran untuk guru, hendaknya menggunakan buku teks bahasa Indonesia Membuatku Semakin Berkarakter, untuk dijadikan buku pendamping dalam proses belajar mengajar. Terutama dalam pembelajaran menulis teks percakapan. Bagi sekolah hendaknya buku teks ini dapat dijadikan koleksi sebagai bahan pustaka.

\section{DAFTAR PUSTAKA}

Cahyani, dkk. 2007. Kemampuan Berbahasa Indonesia di Sekolah Dasar. Bandung: UPI PRESS.

Hadari, Nawawi dan Martini. 1994. Penelitian Terapan. Yogyakarta: Gajah Mada Press

Moleong, Lexy J. 2012. Metodologi Penelitian Kualitatif. Bandung: PT Remaja Rosdakarya

Permendiknas. No 2 Tahun 2008. Peraturan Meteri Pendidikan Tentang Buku.

Riyanto, Agus (2011). Buku Ajar Metodologi Penelitian. Jakarta: EGC 
Sumardi Suryabrata. 2004. Metodologi

Penelitian, Jakarta: PT. Raja Grafindo Persada.

Sutopo. 2006. Metodologi Penelitian Kualitatif. Surakarta: UNS.

Tarigan, Henry Guntur. 2008. Menulis sebagai Suatu Keterampilan Berbahasa. Bandung: Penerbit Angkasa.

Tarigan, Henry Guntur. 2009. Telaah Buku Teks Bahasa Indonesia. Bandung: Angkasa 